\title{
The interaction of a reinforced concrete cylindrical tank with soil in complicated functional conditions
}

\author{
Barbara Kliszczewicz ${ }^{1, *}$ \\ ${ }^{1}$ Silesian University of Technology, Faculty of Civil Engineering, Department of Geotechnics and \\ Roads, 44-100 Gliwice, Akademicka 5, Poland
}

\begin{abstract}
The paper is dedicated to the analysis interactions between the structure of a field-based cylindrical tank made from reinforced concrete and randomly or unevenly distributed strata of subsoil. The numerical analysis with the use of the Z_Soil software package was carried out to investigate how variable geotechnical parameters demonstrated by subsoil strata with a low bearing capacity and a high deformability influence strain and stress of the tank shell and bottom. The arrangement made up of a cylindrical tank and stratified subsoil (its 3D model) was subjected to the analysis with the consideration of the elastic and plastic properties of soil (the Coulomb-Mohr model). The analysis results, presented as diagrams of the structure deformation and stresses illustrate the uneven settlement of the tank shell and its internal strain.
\end{abstract}

\section{Overview of technical infrastructure facilities}

The rapid expansion of human habitats leads to the inevitable need to construct new systems of utilities for built-up areas or upgrade the existing ones. The system of utilities for developed areas is understood as the entire set of facilities, technical equipment and pipelines designed to supply utilities (water, gas and heat) and to drain and discharge wastewater and water from precipitations. This study is dedicated to such facilities as tanks of various design, since tanks are always incorporated into water supply and wastewater drainage networks and perform various roles in such systems.

In the case of water supply systems, any tank-like facilities are constructed both as components of Water Treatment Plants (WTP) as well as tanks designed to store treated water to assure the continuity of its supply, to keep water reserves and to provide water for fire-fighting purposes. The particular role in water supply systems is provided for tanks with clean water. Depending on the role assigned to such tanks, they can be located within regions of water intakes (buffer tanks for water reserves), at water treatment plants (process tanks) or they can be incorporated into water supply networks (network tanks). The roles, purpose and locations of tanks in water supply systems are disclosed in details in studies [1, $2,3]$.

\footnotetext{
* Corresponding author: Barbara.Kliszczewicz@polsl.pl
} 
Wastewater systems also include tank-like facilities that were predominantly applied as components of wastewater treatment plants (e.g. sand and grit traps, sedimentation tanks, biological beds, reaction chambers, digesters and flocculation chambers or mixers) [4]. Examples of such engineering facilities are shown in Fig. 1 and Fig. 2.
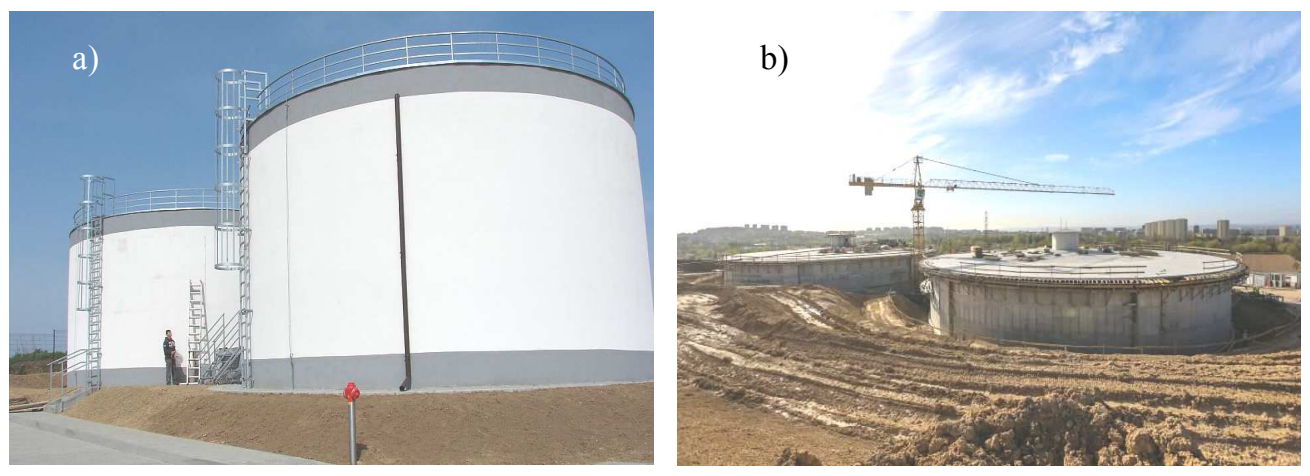

Fig. 1. Tanks used in water supply systems: a) concrete tanks in the Igołomia-Wawrzeńczyce community, (http://o.igwa.pl/index.php?id=zbiorniki_o) b) complex of tanks in Raba II water system (http://wodociagi.krakow.pl/o-firmie/infrastruktura/siec-wodociagowa.html).

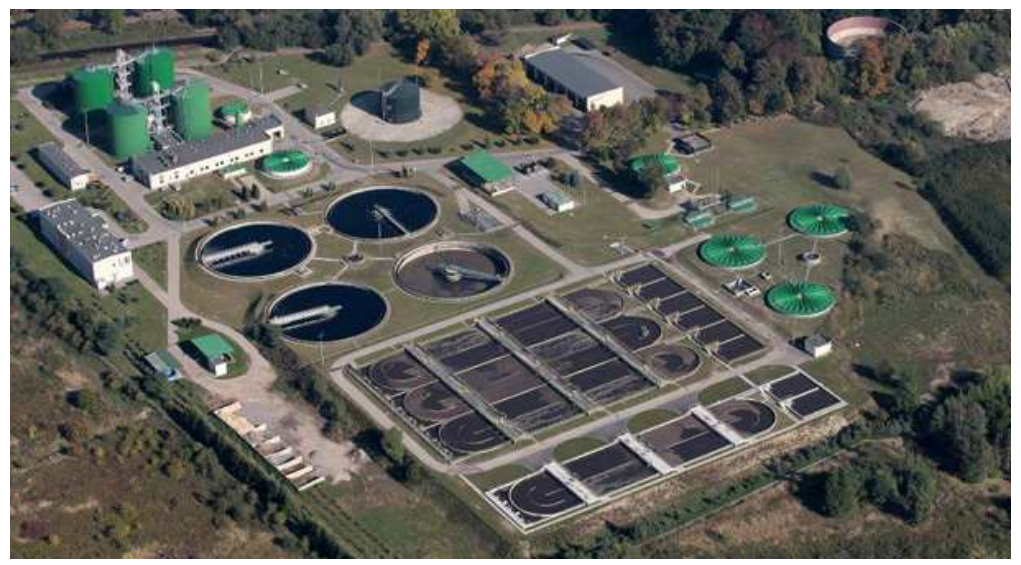

Fig. 2. View of the Central Sewage Treatment Plant in Gliwice (http://pwik.gliwice.pl/materialy/_upload/Zdjecia/COS/COS_panorama.jpg).

The shapes, dimensions and materials applied to the construction of tanks are associated with the technological functions assigned to such tanks. Tanks that are designed for water treatment plants or for wastewater treatment plants are constructed as reinforced concrete structures (field-cast or erected with prefabricated components) or prestressed concrete chambers with a circular or rectangular cross-section. Such tanks can be fully or partly sunk into the soil, but stand-alone or overhead structures are also in use [5, 6]. Tanks shells can be cast together with the bottom slab as monolithic units or can be placed on foundation strips with dilatation gaps between the shells and bottoms. Tank chambers can be open at their tops or covered with lids made up of prefabricated reinforced concrete. Such engineering facilities can be designed with the use of conventional techniques (the theory of slabs and coatings) or numerical methods can be applied. The necessary thickness of tank shells and the amount of reinforcing steel is usually calculated with consideration for the boundary conditions for tank operation (scratching limits) that take into account the key requirements for leak prevention. 


\section{Specification of complicated conditions for tank operation}

The safe operation of tanks with the reliable performance of functions assigned to them is only possible when the engineering process is carried out with the consideration of both key loads (pressure of contained liquid and/or pressure of encapsulating soil, pressure of wind) and some specific circumstances, mostly associated with the interaction between the tank structure and the surrounding soil. Depending on the tank location with respect to the land surface, as well as the design solution applied to the engineering process, such interactions can be of an extremely various nature. Since the scope of this study is limited to field-based tanks sunk into the soil it is possible to specify some sophisticated conditions for the operation of such tank structures. These circumstances are associated with the degree of how much the soil subgrade is complex, which directly affects interactions between the tank and soil. Factors that influence such interactions may include underground mining operations and /or random or uneven stratification of soil subgrades and the local occurrence of soil lens with low bearing capacity.

The effect of underground mining operations on structures of tanks that are fully or party sunk into soil is associated with alterations in the surface-adjacent stratum [7]. The consequences of underground excavations may lead to the formation of vast subsidence troughs (continuous deformations) or local sinkholes (discontinuous deformations). Vertical and horizontal displacements of soil along with entailed deformation of the land surface lead to an occurrence of additional loads acting on structures and resulting in their displacements and deformations. Key impacts that must be taken into account for the analysis of tanks located in areas with mining subsidence include horizontal deformations $\varepsilon$ $[\mathrm{mm} / \mathrm{m}]$ and a curvature of the land surface $\mathrm{K}[1 / \mathrm{km}]$ caused by mining operations. It is an issue that has already been investigated in former studies $[8,9]$ involving numerical studies and dedicated to interactions between a cylindrical tank made of reinforced concrete and the subsoil in mining areas. However, a specific problem that is inherently associated with mining areas consists of the occurrence of geological faults and the effect of such faults onto the additional strain of tanks. An example of such an effect is described in [10] that comprises a description of defects disclosed in reinforced concrete cylindrical tanks encapsulated with soil embankments and located in areas with specific ground conditions (an occurrence of fault areas on the subsoil under tanks and multiple mining operations underground).

Also, geotechnical conditions and the complexity degree of the surrounding subsoil significantly affect interactions between tanks and encapsulating ground, where the random or uneven arrangement of soil strata with an occurrence of interbeddings with low bearing capacity and high deformability is a factor of extreme importance. Such interbeddings may have various thicknesses or may be deposited as local lens-shaped formations. It may lead to the uneven sinking of tank structures into the surrounding soil and, as a consequence, to random and unpredictable strains in tanks shells and bottoms. With regard to the fact that cylindrical tanks are designed as structures with an axial symmetry and placed on or in ground with homogenous or uniformly stratified substrate, the analysis of interactions between tanks and sophisticated subgrade should be considered as an issue of high importance. The 3D nature of such tank structures combined with the random distribution of ground layers exclude the application of conventional computation methods. Such cases can be analyzed exclusively with the use of numerical methods that consider the arrangement made up of a tank and stratified subsoil, mapped onto a multicomponent 3D model. The effectiveness of such analyses depends not only on a degree of how accurate the arrangement is mapped onto the 3D model, but also on the implementation of appropriate constitutive models of the ground with a further analysis in the incremental and iterative mode $[11,12]$. 


\section{Numerical analysis of a cylindrical tank - stratified ground subsoil system}

This study focuses on the evaluation of deformations and strains demonstrated by a fieldbased cylindrical tank made of reinforced concrete and subjected to sophisticated operating conditions. The location of the tank on a randomly stratified substrate, as well as one where the strata exhibits alow bearing capacity are considered such sophisticated operating conditions. The analysis was carried out for a top-open tank fully sunk into the surrounding ground, with a circular cross-section and a diameter of $10.0 \mathrm{~m}$. The tank shell, with a height of $5.0 \mathrm{~m}$ and a thickness of $0.30 \mathrm{~m}$ are cast together, as a monolithic structure, with the tank bottom having a thickness of $0.35 \mathrm{~m}$. The tank is located on stratified ground substrate that was already (bore-hols) bored in four points to the depth of 15.0 below the tank bottom.

A numerical analysis was carried out for the purposefully developed 3D model comprising two structures: a cylindrical tank and a body of soil, allegedly separated from the surrounding ground continuum (Fig. 3).

a)

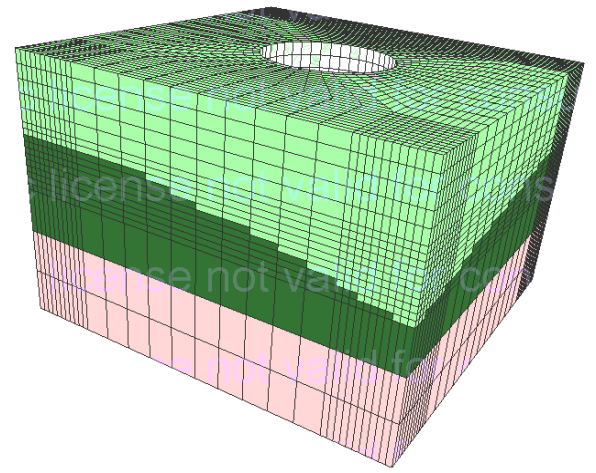

b)

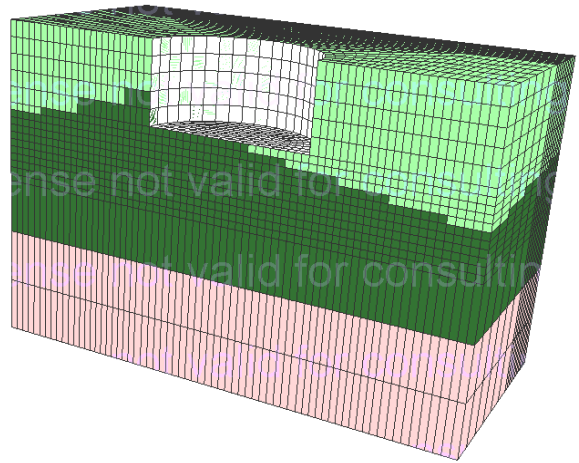

Fig. 3. Model of the cylindrical tank-stratified ground subsoil system: a) general view of the model, b) vertical section of the model.

Specification of the model: number of nodes: 39,336; number of components of a continuum type: 35,511 ; number of components with a shell type: 637 ; number of components with an interface type: 637; number of supports: 4444; number of material zones: 5 . The dimensions of a rectangular prism of soil adopted for the model were: $30.0 \mathrm{x}$ $30.0 \times 20.0[\mathrm{~m}]$. The outer surfaces of the model were provided with a system of supports to enable the vertical displacement of nodes located on vertical planes and the complete fixation of nodes located on the bottom plane of the model. The Boreholes option was applied to distinguish three zones of materials with different geotechnical parameters. The thickness of the bottommost stratum was constant $(6.67 \mathrm{~m})$ whilst the thickness of the two other strata varied from 3.0 to $10.0 \mathrm{~m}$. The reinforced concrete tank located in the model centre was modelled within its range of elasticity (the elastic modulus $E=30 \mathrm{GPa}$ ) whilst the modeling of the soil subgrade was carried out with consideration of plastic properties demonstrated by soil (elastic-perfectly plastic Coulomb-Mohr model). The parameters of the materials in the subgrade strata applied to the analysis are summarized in Table 1.

The investigation program included a simulation of the tank construction process (digging a pit, construction of the tank) with the further filling of the tank with water.

Then computations were made to investigate how the non-homogeneity of the ground subgrade affects the deformation and strain of the tank. The computations were carried out in three steps, where identical geotechnical parameters corresponding to the third stratum were initially adopted for all strata (variant 1 - homogenous subgrade) or parameters for the 
intermediate stratum were varied in further steps (variants 2 and 3). The numerical analyses were carried out with the software package Z_Soil acad. ver. 11.15.

Table 1. Geotechnic parameters of the materials in the subgrade strata.

\begin{tabular}{|l|c|c|c|c|}
\hline & $\begin{array}{c}\text { Young modulus } \\
E[\mathrm{MPa}]\end{array}$ & $\begin{array}{c}\text { Unit weights } \\
\gamma\left[\mathrm{kN} / \mathrm{m}^{3}\right]\end{array}$ & $\begin{array}{c}\text { Friction angle } \\
\Phi\left[{ }^{0}\right]\end{array}$ & $\begin{array}{c}\text { Cohesion } \\
c\left[\mathrm{kN} / \mathrm{m}^{2}\right]\end{array}$ \\
\hline Layer 1 (bottom) & 81.3 & 20 & 33 & 2 \\
\hline $\begin{array}{l}\text { Layer 2 (middle) } \\
\text { variant 2 }\end{array}$ & 2.0 & 18 & 13 & 10 \\
\hline $\begin{array}{l}\text { Layer 2 (middle) } \\
\text { - variant 3 }\end{array}$ & 1.0 & 18 & 13 & 10 \\
\hline Layer 3 (top) & 20.0 & 18 & 35 & 5 \\
\hline
\end{tabular}

Selected results from the analyses (variants 1 and 3) related to the deformation of the soil body and the tank shell are presented in Fig. 4.
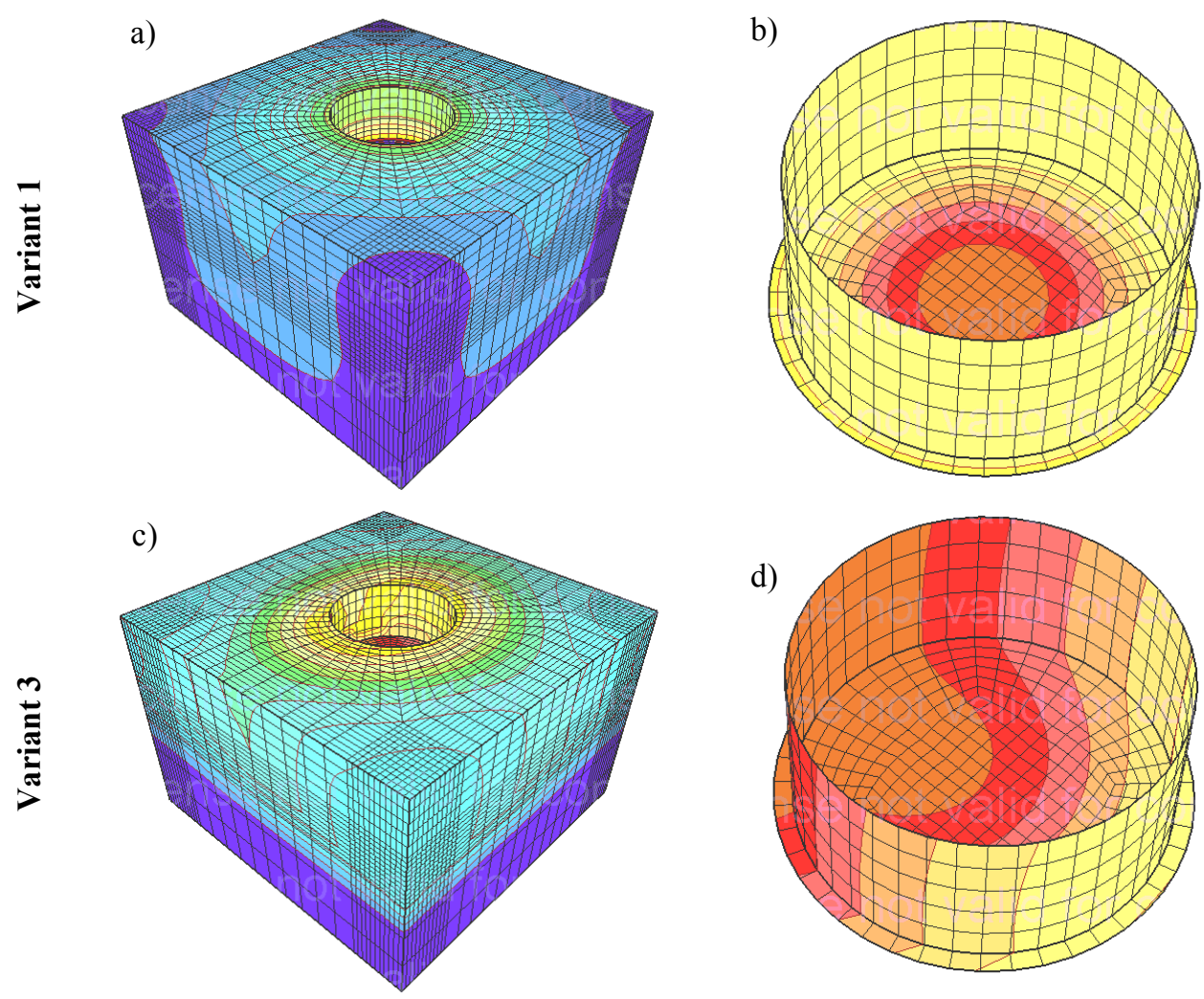

Fig. 4. Maps of the ABS displacements: a) map of the soil body displacements (variant 1), b) map of the tank's shell displacements (variant 1), c) map of the soil body displacements (variant 3), d) map of the tank's shell displacements (variant 3).

Displacements recorded for the model with a uniform ground subgrade (variant 1) and entailed the combined weight of soil and structure of the tank filled with water present a well-organized, regular and symmetrical distribution (Fig. 4a and 4b). However, the occurrence of a stratum with low bearing capacity and variable thickness (intermediate stratum) entails substantial disturbances in distribution of displacement in the soil body and a non-uniform deformation of the model tank shell and bottom (Fig. 4c and 4b). Hence, the cylindrical shell of the tank and its bottom slab is subject to non-uniform strains (Fig. 5). 
a)

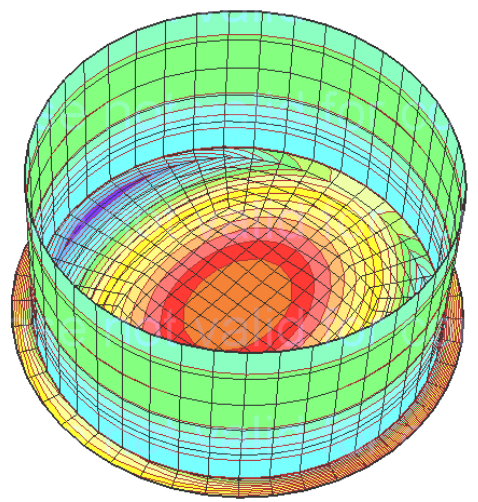

b)

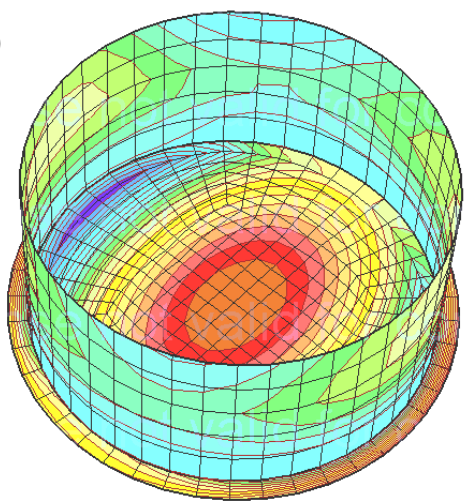

Fig. 5. Maps of stresses (sigma XX) in tank's shell: a) map of stresses - variant 1), b) map of stresses - variant 3.

Deformations of the tank bottom depend on the geotechnical parameters of ground subgrade. It is visible in graphs plotted for the vertical displacements of nodes (Fig. 6) deployed on the tank bottom within the cross-sectional plane for $z=0$. In the case of homogenous ground (variant 1) the bottom deformations are relatively small and symmetrical. After having filled the tank with water, the maximum amplitude of vertical displacement recorded for the central point of the tank bottom (the node \#38089) reached $1.1 \mathrm{~cm}$, which is the sum for the total subsiding of the tank $(0.7 \mathrm{~cm})$ and the bottom convexity $(0.4 \mathrm{~cm})$.

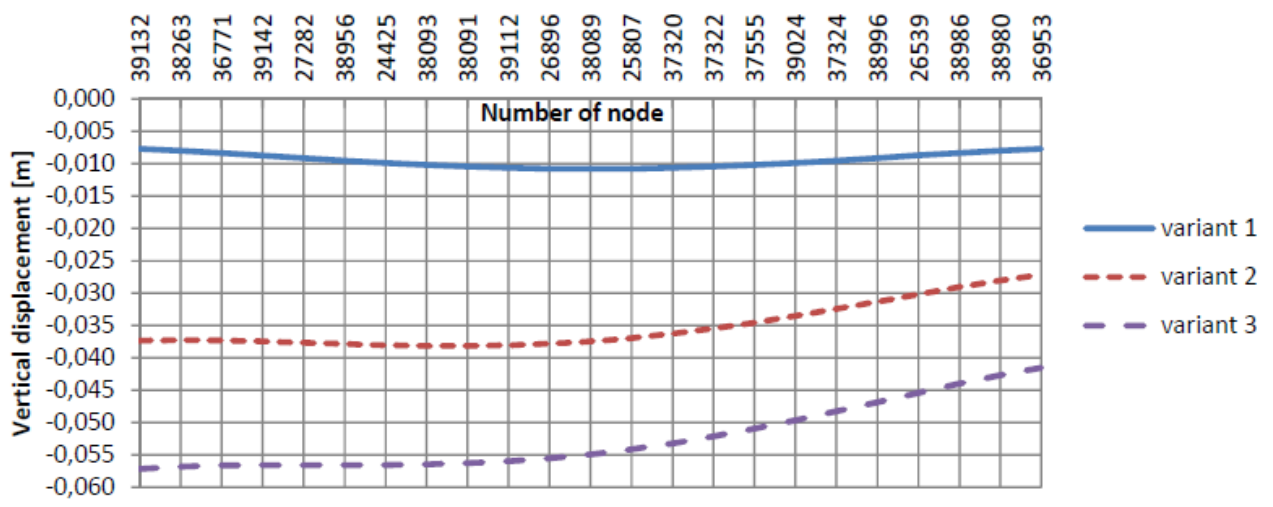

Fig. 6. Vertical displacements of nodes, localized on the bottom of the tank (in section $z=0$ ).

The introduction of a 'weak' stratum with variable thickness leads to non-uniform subsiding of the tank and irregular deformations of the tank bottom. For variant 2 the vertical displacement of the outermost points within the cross-sectional plane under investigation reached the respective distances of $2.8 \mathrm{~cm}$ (node \#36953) and $3.7 \mathrm{~cm}$ (node \#3913). It serves as evidence that the tank has leaned towards the area with higher thickness of the 'weak' stratum. For such a variant the vertical displacement of the bottom central point (node \#38089) is $3.8 \mathrm{~cm}$. On the other hand, a decreasing of the bearing capacity for the 'weak' stratum (variant 3) leads to a more significant but still non-uniform subsiding of the tank with the displacement amplitudes for the outermost points of the bottom section 
plane amounting respectively to $4.2 \mathrm{~cm}$ (node \#36953) and $5.7 \mathrm{~cm}$ (node \#39132). The vertical displacement for the central point of the tank bottom (node \#38089) is $5.5 \mathrm{~cm}$, therefore it is less than for node \#39132. As compared to variant 2, the nature of the tank bottom deformation has changed, which is associated with the formation of plasticized areas in the ground subgrade and its compaction.

\section{Conclusions}

Tank-like civil engineering facilities represent substantial components of the land development systems and the reliable operation of tanks is a precondition for the defect-free service of systems for utility supply. For the correct engineering of cylindrical tanks made of reinforced concrete and designed with an application of the limit state method it is crucial to correctly summarize all loads and impacts affecting the tank under design and to consider their possible combinations. Tank shells and bottoms are frequently engineered with the use of dedicated application software packages that incorporate a simplified and actually inadequate model of ground subgrade, i.e. the Winkler elastic model, which is completely disparate to reality. The interactions between such facilities and subgrade can be considered to a broader extent when software packages oriented to geotechnical phenomena are applied, since they incorporate built-in, advanced models of ground substrate that consider the elastic properties of soil. Such software packages enable investigation of interactions between tanks and ground under sophisticated soil conditions (e.g. impact of mining operations, complex stratification of subgrades, occurrence of interbeddings made up of 'weak' soil with low bearing capacity and high deformability).

An example of such an analysis is presented in this study that is dedicated to cylindrical, field-based tanks made of reinforced concrete and encapsulated with soil of specific properties (an occurrence of a stratum with 'weak' soil and with large fluctuations of its thickness). The interactions between the tank and its subgrade were investigated with the use of a 3D model that reflected the actual arrangement made up of a cylindrical tank and ground substrate. The numerical analysis of an incremental and iterative nature (the software package Z_Soil ver. 11.15) made it possible to investigate the effect of geotechnical parameters proprietary to a 'weak' stratum onto tank deformations and the strain of its components. The analysis results, i.e. the distribution of stresses within the tanks structure and its deformations were compared against the results obtained for the reference model (the arrangement made up of a cylindrical tank and homogenous ground subgrade). The investigation outcome served as proof that the occurrence of non-uniform and non-homogenous strata of ground substrate, in particular strata with poor mechanical parameters, substantially influences the deformation and strain of the tank structure. Tank subsiding becomes non-uniform, which leads to the alteration of stress distribution in the tank shell and bottom.

In spite of the fact that the completed analysis is merely an example, and its results are correct only for the scope of input data assumed for computations, it enables formulation of more general conclusions. When detached tanks, particularly of rather large dimensions, are going to be built in a field it is mandatory to carry out a detailed investigation of the ground substrate. When an occurrence of 'weak' soil strata with low bearing capacity and high deformability is detected, it is necessary to consider a partial replacement of the soil or, when such a replacement is technically infeasible or not cost-effective, one of contemporary available methods for soil reinforcement should be applied. 


\section{References}

1. Z. Pląskowski, M. Roman, Konstrukcje budowlane w stacji uzdatniania wody (Civil engineering structures for water treatment plants), Arkady, Warszawa (1979) (in Polish)

2. E. Osuch-Pajdzińska, M. Roman, Sieci i obiekty wodociągowe (Water supply networks and facilities), WPW, Warszawa (2008) (in Polish)

3. Z. Suligowski, Zaopatrzenie w wodę, (Water supplies) Wyd. ART., Olsztyn (1999) (in Polish)

4. Z. Pląskowski, M. Roman, Konstrukcje budowlane w oczyszczalniach ścieków (Civil engineering structures for wastewater treatment plants), Arkady, Warszawa (1973) (in Polish).

5. A. Halicka, D. Franczak, Projektowanie zbiorników żelbetowych, t.2, (Engineering of reinforced concrete tanks, vol. 2) PWN (2014) (in Polish)

6. J. Kobiak, W. Stachurski, Konstrukcje żelbetowe, t. 4 (Reinforced concrete structures, vol. 4), Arkady, Warszawa (1991) (in Polish)

7. J. Kwiatek, Obiekty budowlane na terenach górniczych (Civil engineering facilities on areas with mining operations), GIG, Katowice (2007) (in Polish)

8. B. Kliszczewicz, Analiza współdziałania żelbetowego zbiornika cylindrycznego z podłożem gruntowym poddanym rozpełzaniu. Rozprawa doktorska. Pol. Śl. (Analysis of interactions between a reinforced concrete cylindrical tank and soil subgrade susceptible to creeping. PhD Thesis, Silesian University of Technology) (1998) (in Polish)

9. B. Kliszczewicz, Projektowanie zbiorników na terenach górniczych, Konf. NaukTechn. Problemy projektowania i ochrony obiektów budowlanych na terenach górniczych, (Engineering of tanks on areas with mining operations. Scientific and Technical Conference: Issues of Engineering and Protection of Civil Facilities on Areas with Mining Operations) ITB, Rudy Raciborskie, (1999) (in Polish)

10. A. Ajdukiewicz, L. Szojda, G. Wandzik, Analiza wpływu deformacji podłoża wywołanych eksploatacją górniczą na awaryjny stan żelbetowych zbiorników na wodę, Konf. Nauk.-Techn. Bezpieczeństwo i ochrona obiektów budowlanych na terenach górniczych, (Analysis of Impacts from Subgrade Deformations Caused by Mining Operations onto Deteriorated Condition of Reinforced Concrete Tanks for Water Storage, Scientific and Technical Conference: Issues of Engineering and Protection of Civil Facilities on Areas with Mining Operations)GIG, Rytro (2012) (in Polish)

11. B. Kliszczewicz, M. Gryczmański, Wpływ historii obciążenia na pracę statyczną cylindrycznego zbiornika na sprężyście-idealnie plastycznym podłożu górniczym. I Problemowa Konferencja Geotechniki : Współpraca budowli z podłożem gruntowym, (Influence of Past History of Loads onto Static Operation of a Cylindrical Tank Located on an Ideally Elastic Subgrade in Areas with Mining Operations, $1^{\text {st }}$ ProblemRelated Conference of Geotechnical Engineering: Interactions between structures and soil subgrade), Białystok (1998) (in Polish)

12. P. Lewiński, Analiza współpracy żelbetowych zbiorników cylindrycznych z podłożem (Analysis of interactions between cylindrical reinforced concrete tanks and soil subgrade), ITB (2007) (in Polish) 